\title{
Characterization of the essential oil from cone-berries of Juniperus communis L. (Cupressaceae)
}

\author{
EWA MAJEWSKA*, MARIOLA KOZŁOWSKA, DOROTA KOWALSKA, ELIZA GRUCZYŃSKA
}

Warsaw University of Life Sciences - SGGW

Faculty of Food Sciences

Departament of Chemistry

Nowoursynowska 159c

02-776 Warsaw, Poland

*corresponding author: phone: +48 2259376 12, fax: +48 225937 635, e-mail: ewa_majewska@sggw.pl

\section{Summary}

Juniperus communis L. (Cupressaceae) is a plant widely cultivated in the Northern hemisphere. Juniper berries, the fruit of Juniperus communis L. are a highly valued, essential oil-rich plant material used traditionally in folk medicine as antiseptic, diuretic, antirheumatic, anti-inflammatory, antibacterial and antifungicidal agent. This paper reviews information on extraction methods of the essential oil from the juniper berries, its chemical composition and antimicrobial as well as antioxidant properties.

Key words: Juniperus communis L., essential oils, Juniperi pseudofructus

\section{INTRODUCTION}

Juniperus L. (consisting of approximately 70 species and 40 varieties) is the second most diverse genus of the conifers. The genus is divided into three sections, and one of them is Juniperus (syn: sect. Oxycedrus Spach), containing 12 species. Juniperus communis L. (Cupressaceae Rich. ex Bartl.), a highly variable taxon distributed in Northern hemisphere (including Baltic Sea region), has the largest distribution of all juniper species.

The cone-berries of $J$. communis (known as Juniperi pseudofructus) are used since ancient times in folk medicine to cure cystitis, digestive disorders, in therapy of chronicle arthritis and other indications. The berries contain essential oil with characteristic conifer-like aroma and bitterly taste. Many constituents present in juniper essential oil are responsible for the oil biological properties. Antibacterial and antifungal properties of the essential oils as well as of oil constituents are well documented [1]. Essential oil or some of its constituents have found application as antimicrobial agents for food preservatives, in clinical microbiology or in pharmaceutical preparations. The juniper essential oil is used in many 
industries, for example in food industry to flavor alcohols such as gin or in production of blended teas. The health benefits of juniper essential oil can be attributed to its properties as an antiseptic, sudorific, antirheumatic, depurative, antispasmodic, stimulating, stomachic, astringent, carminative, diuretic, rubefacient, vulnerary and tonic substance.

Commercial juniper berry essential oil is rarely a true distillate from berries and may be a by-product from gin or brandy manufacture. In addition to berries, also branches, needles and wood of juniper contain essential oils. Juniper needles contain 0.2$1.0 \%$ of volatile oil. Oil yield depends on the degree of ripeness, seasonal variations, environmental conditions (temperature, sunlight, photoperiod), age of plant latitude and altitude of growing site, a role in selective browsing damage by local herbivores and other factors. The average yield of the essential oil varies from 0.47 to $0.75 \%$ in dried needle with young juniper branches and $0.1-0.28 \%$ in dried branches according to the month of collection $[2,3]$. The most significant changes in the content of the oil were found in spring-summer period of vegetation.

There is no monograph concerning juniper needles or branches in European Pharmacopoeia (EP) [4], but the monograph of Juniperi pseudofructus describes them as the ripe cone-berry of J. communis L., which may not contain less than $10 \mathrm{ml} / \mathrm{kg}$ of essential oil. The amount of the essential oil can be up to $3 \%$.

\section{Botanical aspects}

J. communis is an evergreen, perennial, long-lived (to 600 years or more) coniferous plant having the largest range of any woody plant in the cool temperate geographical regions of Northern Hemisphere, from the southern part of the Arctic, in mountains, to around a latitude of $30^{\circ}$ north in Europe, Asia and North America. J. communis is a globally distributed species exhibiting a wide range of ecological adaptations. A wide geographical distribution is the main reason for the remarkable variation in the morphological characteristics and chemical composition of the secondary metabolites of J. communis [5].

J. communis has green and sharp leaves (needles) in whorls of a three; the leaves remain on the branch for up to 4 years. J. communis is a dioecious species: male and female cones grow on separate wind-pollinated plants. The plant blooms in April-May, however the cones of J. communis maturation time is late autumn of the second year. Therefore, the unripe second year and ripe third year berries may be collected from the same plant simultaneously. The spherical cones are berry-like, blue-black with a waxy coating and usually have three (or sometimes six) scales, each scale with a single seed. J. communis is a very slowly growing plant reaching approximately 20 and $50 \mathrm{~cm}$ in height after 5 and 10 years, respectively [5].

The cultivation of J. communis is not very problematic. The maintenance of plant is low, it prefers full sun and a well drained, slightly acidic soil. This popular garden shrub is resistant to low temperature, harsh weather conditions and environmental pollution.

\section{Extraction of essential oil from berries}

Most of the organs of J. communis contain essential oil, but is extracted mainly from berries, needles and branches. Traditionally, the oil is collected by extraction using organic solvent: methanol, nhexane, but the main process applied is distillation of the crushed, dried, partially dried or fermented berries [6].

Juniper essential oil is usually present in berries at relatively low concentrations $(0.2-3.42 \%)$ and recovery techniques of high performance are required to achieve high oil yields. Various techniques have been used for juniper oil extraction such as hydrodistillation $[7,8]$, supercritical carbon dioxide extraction [9-12], solvent extraction [10] and simultaneous distillation extraction method [8].

Damjanović et al. isolated volatile compounds from berries of common juniper by three different techniques: hydrodistillation, hexane extraction and supercritical $\mathrm{CO}_{2}$ extraction [10]. They obtained the essential oil with yield of $2.17 \%$ using hydrodistillation, the hexane extraction yield was $5.31 \%$ and supercritical $\mathrm{CO}_{2}$ extraction yield was $0.96 \%$. Chemical composition analyses conducted by GC/MS revealed that the samples differed quantitatively and qualitatively. The concentrations of monoterpene hydrocarbons ( $\alpha$-pinene, sabinene, myrcene) were higher in the hydrodistilled oil, while some less volatile compounds were present in extracts, especially in hexane extract. 
Each technique of extraction has particular advantages and disadvantages. Nevertheless, juniper oil is most frequently obtained by hydrodistillation. A Clevenger-type hydrodistillation apparatus is normally used for the recovery of juniper oil in the laboratory, while different types of water, water-steam and direct steam distillation units of different size and design are applied for industrial recovery. Hydrodistillation not only produces high quality juniper oil, but it is also relatively simple and safe to operate, as compared to other extraction techniques. It is also environmental friendly [6].

In the last decade, classic hydrodistillation has been improved by involving microwave irradiation to heat the water suspension of the plant material. Microwave-assisted hydrodistillation (MAHD) has been widely used to isolate essential oils from various plant materials [13-15]. In MAHD the sample reaches its boiling point very rapidly, leading to a very short extraction. In addition, with the microwave distillation technique it is possible to achieve distillation with the indigenous water of the fresh plant material. The use of MAHD at present is limited to laboratory scale, and its future industrial application is dependent on the scalable design of functional microwave equipment, which requires greater investment and better process quality control.

\section{Chemical composition of juniper berry essen- tial oil}

The chemical composition of essential oils obtained by hydrodistillation from juniper leaf (needles) [16-20] and berries [19-22] has been studied by several authors.

Dried berries of J. communis contain $30-40 \%$ of sugars (mainly glucose and fructose), $1.2-10 \%$ resin and considerable amounts of organic acids and essential oils $(0.2-3 \%)$.

According to monographs of juniper oil $(\mathrm{Ju}$ niperi aetheroleum) in European Pharmacopoeia [4], the essential oil obtained by steam distillation from the ripe, non-fermented berry cones of $J$. communis L. and the percentages of the components are placed within following ranges: $\alpha$-pinene $20-50 \%$, sabinene less than $20 \%, \beta$-pinene $1-12 \%$, $\beta$-myrcene $1-35 \%, \alpha$-phellandrene less than $1 \%$, limonene $2-12 \%$, terpinen-4-ol $0.5-10 \%$, bornyl acetate less than $2 \%$, and $\beta$-caryophyllene less than $7 \%$.
Using GC/FID and GC/MS assays, 70 compounds were identified in the essential J. communis oil, although, some reports claim that there are more than 100 chemical compounds [23]. The composition of the essential oil varies upon origin of berries but consists mainly of monoterpene hydrocarbons (about $60 \%$ of the essential oil). The major constituent of the unripe and ripe berry essential oils of $J$. communis from European countries is $\alpha$-pinene [10,16,17, 22, 24-26], (tab. 1). The essential oils may comprise about $35 \%$ to $57 \%$ of $\alpha$-pinene. The second most abundant constituent of the essential oil is sabinene which content ranges from $0.17 \%$ in oil from Olimp (Grece) to $28.8 \%$ in oil from sabinene chemotype berries [26]. Juniper berry oils of sabinene chemotype have been found only in high mountains. The juniper essential oil is also rich in myrcene which may usually constitute $8-20 \%$ of volatiles. Myrcene is the main chemical compound which allows the differentiation between berry oil and needle oil: the needle oil may comprise only up to $5 \%$ of myrcene, whereas berry oil contains it much more, up to $20 \%$ [27]. The major oxygenated terpenoids found in juniper oil is terpinen-4-ol (0.05-2.60\%). Berry essential oil contains also sesquiterpenes which amount from about $2 \%$ in oil from Macedonia (Greece) to about $10 \%$ in oil from Olimp (Greece).

Most of the monoterpene hydrocarbons found in the juniper berry essential oil show optical activity, but only few articles describe enantiomeric composition of the oil. Sabinene and $\beta$-pinene exist only in one enantiomeric form, sabinene as the dextrorotary $(+)$-form and $\beta$-pinene as the laevorotatory $(-)$-form $[28,29] . \alpha$-pinene appears in both enantiomers. In the oil from berries collected in northern Poland $(R)-(+)-\alpha$-pinene prevails at comparable levels, varying from 33 to $62 \%$, whereas in the oil from France and different locations in Poland (-)- $\alpha$-pinene dominates. In the berry essential oil a large excess of (+)-limonene over its (-)-antipode is observed, which seems to be characteristic of the Rutaceae, while for essential oils from the Pinaceae (-)-limonene is most abundant [28].

For comparison, table 1 summarizes chemical composition of juniper berries oil from several European countries. Changes in the composition of essential oil can be caused by environmental factors, such as soil or climate conditions as well as by different harvesting methods or distillation techniques. 
Table 1.

Percentage composition of selected compounds found in the essential oil of cone-berries of Juniperus communis

\begin{tabular}{|c|c|c|c|c|c|c|c|}
\hline \multirow[b]{2}{*}{ Compound } & \multicolumn{7}{|c|}{ Geographical origin of berries } \\
\hline & $\begin{array}{l}\text { Lithuania } \\
\text { [24] }\end{array}$ & $\begin{array}{l}\text { Sardinia } \\
\text { [16] }\end{array}$ & $\begin{array}{c}\text { Montenegro } \\
{[10]}\end{array}$ & $\begin{array}{l}\text { Greece } \\
\text { Olimp } \\
{[25]}\end{array}$ & $\begin{array}{c}\text { Greece } \\
\text { Macedonia } \\
{[26]}\end{array}$ & $\begin{array}{c}\text { Commercial } \\
\text { product from } \\
\text { Bulgaria } \\
{[17]}\end{array}$ & $\begin{array}{c}\text { Commercial } \\
\text { product from } \\
\text { Germany } \\
{[22]}\end{array}$ \\
\hline & \multicolumn{7}{|c|}{ Monoterpene hydrocarbons [\%] } \\
\hline$\alpha$-Thujene & 0.00 & 0.53 & 0.10 & 0.08 & $-*$ & 0.90 & 0.70 \\
\hline$\alpha$-Pinene & 43.50 & 52.26 & 39.20 & 42.55 & 57.06 & 51.4 & 35.4 \\
\hline Camphene & 0.20 & 0.22 & 0.20 & 0.21 & 0.31 & 0.80 & 0.50 \\
\hline Sabinene & 1.10 & 5.58 & 17.8 & 0.17 & 6.08 & 5.80 & 7.60 \\
\hline$\beta$-Pinene & 1.60 & 2.86 & 0.00 & 1.65 & 3.41 & 5.00 & 3.30 \\
\hline Myrcene & 19.60 & 15.32 & 18.20 & 8.10 & 10.74 & 8.30 & 15.3 \\
\hline$\alpha$-Phellandrene & 0.00 & 0.00 & 0.10 & traces & 0.40 & - & - \\
\hline$\beta$-Phellandrene & 0.40 & 0.00 & - & 0.11 & - & 0.50 & - \\
\hline$\delta$-3-Carene & 0.00 & 0.00 & 1.00 & 0.02 & 0.02 & 0.20 & 0.10 \\
\hline$\alpha$-Terpinene & 0.00 & 0.00 & - & 0.02 & 0.12 & 0.10 & 0.50 \\
\hline$p$-Cymene & 0.00 & 0.25 & 0.70 & 0.11 & 0.08 & 0.90 & 2.10 \\
\hline Mimonene & 2.40 & 3.11 & 5.20 & 0.83 & 1.73 & 5.10 & 7.30 \\
\hline$\gamma$-Terpinene & 0.40 & 0.52 & 1.40 & 0.05 & 0.34 & 0.20 & 1.80 \\
\hline Terpinolene & 0.10 & 0.49 & - & 0.41 & 0.62 & 0.40 & 1.20 \\
\hline \multirow[t]{2}{*}{ Total } & 69.30 & 81.14 & $\sim 83.9$ & 54.31 & $\sim 80.91$ & $\sim 79.6$ & $\sim 75.8$ \\
\hline & \multicolumn{7}{|c|}{ Derivatives of monoterpenes [\%] } \\
\hline Linalool & 0.00 & 0.00 & 0.10 & 0.11 & 0.26 & 0.10 & 0.20 \\
\hline Terpinen-4-Ol & 0.40 & 1.51 & 2.60 & 0.74 & 0.05 & 0.90 & 2.40 \\
\hline$\alpha$-Terpineol & 0.50 & 0.00 & 0.20 & 0.57 & 0.85 & 0.20 & 0.20 \\
\hline Citronellol & 0.00 & 0.00 & - & 0.20 & 5.06 & - & - \\
\hline Camphor & 0.00 & 0.00 & - & 0.53 & - & - & - \\
\hline Bornyl acetate & 0.80 & 0.66 & 0.20 & 0.59 & 1.08 & 0.30 & 0.20 \\
\hline \multirow[t]{2}{*}{ Total } & 1.70 & 2.17 & $\sim 3.10$ & 2.74 & $\sim 7.30$ & $\sim 1.50$ & $\sim 3.00$ \\
\hline & \multicolumn{7}{|c|}{ Sesquiterpenes [\%] } \\
\hline$\alpha$-Copaene & 0.00 & - & - & - & - & 0.50 & 0.50 \\
\hline$\alpha$-Cubebene & 0.00 & 1.25 & 0.40 & 1.29 & - & 0.60 & 0.50 \\
\hline$\beta$-Caryophyllene & 0.10 & 0.00 & 1.00 & 0.77 & 1.86 & 2.00 & 4.20 \\
\hline$\alpha$-Humulene & 0.30 & 0.81 & 0.70 & 0.72 & - & 1.30 & 1.20 \\
\hline Germacrene-D & 0.40 & 6.69 & 3.80 & 3.99 & - & 1.10 & 1.80 \\
\hline$\alpha$-Muurolene & 0.30 & 0.00 & 0.20 & 0.52 & - & 0.40 & - \\
\hline$\gamma$-Cadinene & 0.60 & - & 0.20 & 0.80 & - & 0.50 & - \\
\hline$\delta$-Cadinene & 2.10 & - & 0.70 & 2.61 & - & 0.80 & 1.50 \\
\hline Total & 3.80 & $\sim 8.75$ & 7.00 & 10.70 & $\sim 1.86$ & 7.20 & $\sim 9.70$ \\
\hline
\end{tabular}

*the dash means no information given by the authors

\section{Antimicrobial activity of juniper berry essen- tial oil}

The essential oil from cone berries of J. communis showed antimicrobial activity of Gram-positive bacteria: Bacillus cereus ATCC 11778, Bacillus subtilis
NCTC 8236, Micrococcus flavus MFBF, Micrococcus luteus ATCC 9341, Staphylococcus aureus ATCC 6538, Staphylococcus aureus MFBF, Staphylococcus epidermidis MFBF, Enterococcus faecalis MFBF. The antimicrobial activity was determined by the diffusion method and the inhibition zones of tested 
bacteria ranged from 10 to $16 \mathrm{~mm}$ [30]. Gram-negative bacteria were also sensitive to juniper essential oil. The bacterial strains such as Serratia spp. MFBF, Salmonella enteritidis MFBF, Proteus mirabilis MFBF, Shigella sonnei MFBF, Klebsiella oxytoca MFBF and Yersinia enterocolitica MFBF had inhibition zones from 8 to $17 \mathrm{~mm}$. Citrobacter freundii MFBF and Escherichia coli MFBF remained resistant to the essential oil. MIC for the bacterial strains were very high, ranging from 8 to $70 \%(v / v)$ of essential oil.

Pepeljnjak et al. also tested antifungal properties of the essential oil from cone berries of J. communis [30]. Candida albicans MFBF, C. krusei MFBF, C. tropicalis MFBF, C. parapsilosis MFBF, C. glabrata MFBF, C. kefyr MFBF, C. lusitaniae MFBF, Cryptococcus neoformans MFBF, Geotrichum candidum MFBF and Hansenula anomala MFBF were sensitive to the essential oil, and the inhibition zones varied from 8 to $17 \mathrm{~mm}$. Among the dermathophyte species tested, Microsporum gypseum MFBF and Trichophyton rubrum MFBF showed inhibition zones between 10 and $14 \mathrm{~mm}$. Yeast, yeast-like fungi and dermatophytes were found to be very sensitive to juniper essential oil, with $M I C$ values lower than $10 \%(v / v)$. The lowest values of $M I C$ of the essential oil against fungal strains indicate that the main compounds present in the oil-terpen hydrocarbons (pinene, sabinene, mircene and limonene) had stronger antifungal activity than the antibacterial.

Essential oil of J. communis growing wild in Kosovo showed antimicrobial activity against $S$. aureus ATCC 25923, E. coli ATCC 25922 and Hafnia alvei PTCC 2005 but was not active against Pseudomonas aeruginosa ATCC 27853 [31].

The mechanism of antimicrobial action of terpenes is not fully understood but it is speculated to involve membrane disruption by the lipophilic compounds [32]. Antimicrobial activity of different fractions of the essential oil of $J$. communis showed that fractions containing high concentrations of $\alpha$-pinene and sabinene effectively inhibited the growth of microorganisms. The fractions containing pure $\alpha$-pinene and a mixture of $\alpha$-pinene and sabinene successfully inhibited all bacterial strains especially the growth of fungi and yeast.

According to the experiments conducted by Filipowicz et al. it can be assumed that the antimicrobial effect of the juniper berry oil is the result of synergistic co-operation of a few constituents present in the oil in exceptional concentrations, namely
(-)- $\alpha$-pinene, $p$-cymene and $\beta$-pinene [29]. Further studies are required to explain this phenomenon entirely.

\section{Antioxidant activity of juniper berry essential oil}

The antioxidant activity of essential oils from different juniper berry species has been established in vitro [33]. Anti-radical activity depends on the oil components, namely their chemical nature and concentration [34]. Regardless of its origin, juniper berry essential oil contains predominantly terpene hydrocarbons. In many cases, the essential oil antioxidant activity cannot be attributed to the dominant compounds $\alpha$ - and $\beta$-pinene. These monoterpene hydrocarbons in juniper berry essential oil do not contribute to a significant inhibition of malondialdehyde formation [35]. The carriers of antioxidant properties in relation to lipid peroxidation in both its stages are $\alpha$ - and $\gamma$-terpinenes and, to a significantly lesser extent, their sesquiterpene analogues. The activity of $\alpha$ - and $\gamma$-terpinenes is comparable to that of $\alpha$-tocopherol. This has been established both for juniper essential oils [34] and for pure terpene hydrocarbons: terpinolene, $\alpha$-terpinene and $\gamma$-terpinene [35]. Myrcene, $\alpha$ - and $\beta$-pinene only exhibit lipid peroxidation in the second stage; sabinene, limonene, $\alpha$-pinene and myrcene demonstrate anti-radical activity in relation to DPPH radical. Mainly $\beta$-pinene and limonene are responsible for the scavenging effect of $\mathrm{OH}^{\circ}$ and the protection of deoxyribose against degradation. The $\mathrm{O}_{2}{ }^{-}$neutralization is determined by germacrene-D [33].

The antioxidant capacity of the essential oil from cone-berries of J. communis was evaluated in vitro by 2,2-diphenyl-1-picrylhydrazyl (DPPH) scavenging, 2,2'-azino-bis(3-ethylbenzothiazoline-6-sulphonic acid) (ABTS) radical cation scavenging, hydroxyl radical $\left(\mathrm{OH}^{\circ}\right)$ scavenging and chelating capacity, superoxide radical $\left(\mathrm{O}_{2}{ }^{-}\right)$scavenging and xanthine oxidase inhibitory effects, hydrogen peroxidase scavenging $[17,22]$. The antioxidant activity of the oil attributable to electron transfer made juniper berry essential oil a strong antioxidant, whereas the antioxidant activity attributable to hydrogen atom transfer was lower. Lipid peroxidation inhibition by the essential oil in both stages, i.e., hydroperoxide formation and malondialdehyde formation, was less efficient than the inhibition by butylated hydroxytoluene (BHT). These effects were confirmed in in vivo studies in which model organism Saccharomyces cerevisiae was used $[17,22]$. The compounds present in juniper 
berry essential oil blocked the oxidation processes in yeast cells by increasing activity of the antioxidant enzymes superoxide dismutase (SOD), catalase (CAT) and glutathione peroxidase (GP). The biological effects of juniper berry essential oil in vivo were directly dependent on the concentrations applied.

Ethical approval: The conducted research is not related to either human or animal use.

Conflict of interest: Authors declare no conflict of interest.

\section{CONCLUSIONS}

The juniper berry essential oil has a rich history of traditional uses and benefits. The essential oil is usually obtained by hydrodistillation. Chemical composition of the oil has a huge range of variability (both quantitative and qualitative) depending on plant origin and individual plant level as well. The oil is mainly composed of monoterpenes, including $\alpha$-pinene, myrcene and sabinene as major components, lesser amounts of sesquiterpenes and other volatile compounds are found. The berry essential oil shows antimicrobial and antioxidant activity, which is applied in food processing, the pharmaceutical and cosmetic industries.

\section{REFERENCES}

1. Bais S, Gill NS, Rana N, Shandil S. A phytopharmacological review on a medicinal plant: Juniperus communis. Int Scholar Res Notices 2014; 1-6. doi: http://dx.doi.org/10.1155/2014/634723

2. Raal A, Kanut M, Orav A. Annual variation of yield and composition of the essential oil of common juniper (Juniperus communis L.) branches from Estonia. Baltic Forestry 2010; 16(1):1392-1355.

3. Butkienë R, Büdiene J, Judžentiene A. Variation of secondary metabolites (essential oils) in various plant organs of Juniperus communis L. wild growing in Lithuania. Baltic Foresty 2015; 21(1):1392-1355.

4. European Pharmacopoeia. 2017. $9^{\text {th }}$ Ed. Council of Europe, Strasbourg, 1404-1405.

5. Adams RP. Junipers of the World: The Genus Juniperus. $4^{\text {th }}$ ed. Trafford Publishing Co. Vancouver 2004.
6. Milojević SŽ, Stojanović TD, Palić R, Lazić ML, Veljković VB. Kinetics of distillation of essential oil from comminuted ripe juniper (Juniperus communis L.) berries. Biochem Engin J 2008; 39:547-553. doi: http://dx.doi.org/10.1016/j. bej.2007.10.017

7. Butkienë R, Nivinskienë O, Mockutë D. Chemical composition of unripe and ripe berry essential oils of Juniperus communis L. growing in Vilnius district. Chemija 2004; 15:57-63.

8. Chatzopoulou P, Katsiotis ST. Procedures influencing the yield and the quality of the essential oil from Juniperus communis L. berries. Pharm Acta Helv 1995; 70:247-253.

9. Barjaktarević B, Sovilj M, Knez Ž. Chemical composition of Juniperus communis L. fruits supercritical $\mathrm{CO}_{2}$ extracts: dependence on pressure and extraction time. J Agric Food Chem 2005; 53:2630-2636. doi: http://dx.doi.org/10.1021/ jf048244g

10. Damjanowić B, Skala D, Petrović-Djakov D, Baras J. A comparison between the oil, hexane extract and supercritical carbon dioxide extract of Juniperus communis L. J Essent Oil Res 2003; 15:91-93. doi: http://dx.doi.org/10.1080/1041290 5.2003.9712076

11. Damjanowić B, Skala D, Baras J, Petrović-Djakov D. Isolation of essential oil and supercritical carbon dioxide extract of Juniperus communis L fruits from Montenegro. Flavour Fragr J 2006; 21:875880. doi: http://dx.doi.org/10.1002/fff.1711

12. Marongiu B, Porcedda S, Piras A, Sanna G, Murreddu M, Loddo R. Extraction of Juniperus communis L. ssp. nana Willd. essential oil by supercritical carbon dioxide. Flavour Fragr J 2006; 21:148-154. doi: http://dx.doi.org/10.1002/ ffj. 1549

13. Ferhat MA, Meklati BY, Chemat F. Comparison of different isolation methods of essential oil from citrus fruits cold pressing hydrodistillation and microwave dry distillation. Flavour Fragr J 2007; 22:494-504. doi: http://dx.doi.org/10.1002/ ffj. 1829

14. Karakaya S, El SN, Karagozlu N, Sahin S, Sumni G, Bayramoglu B. Microwave-assisted hydrodistillation of essential oil from rosemary. J Food Sci 
Technol 2014; 51:1056-1065. doi: http://dx.doi. org/10.1007/s13197-011-0610-y

15. Bustamante J, van Stempvoort S, Garcia-Gallarreta M, Houghton JA, Briers HK, Budarin V et al. Microwave assisted hydro-distillation of essential oils from wet citrus peel waste. J Cleaner Prod 2016; 137:598-605. doi: http://dx.doi. org/10.1016/j.jclepro.2016.07.108

16. Angioni A, Barra A, Russo MT, Coroneo V, Dessi $S$, Cabras P. Chemical composition of the essential oils of Juniperus from ripe and unripe berries and leaves and their antimicrobial activity. J Agric Food Chem 2003; 51(10):3073-3078. doi: http:// dx.doi.org/0.1021/jf026203j

17. Höferl M, Stoilova I, Schmidt E, Wanner J, Jirovetz L, Trifonova D et al. Chemical composition and antioxidant properties of Juniper berry (Juniperus communis L.) essential oil on the antioxidant protection of Saccharomyces cerevisiae model organism. Antioxidants 2014; 3:81-98. doi: http://dx.doi.org/10.3390/antiox3010081

18. Kumar A, Yadav LBS, Ahmad J, Dubey N, Puri S. Chemical composition of commercial Juniperus communis L. leaf oil. J Essent Oil Bearing Plants 2007; 10:310-313. doi: http://dx.doi.org/10.1080/ 0972060X.2007.10643560

19. Orav A, Kailas T, Müürisepp M. Chemical investigation of the essential oil from berries and needles of common juniper (Juniperus communis L.) growing wild in Estonia. Nat Prod Res 2010; 24(19):1789-1799. doi: http://dx.doi. org/10.1080/14786411003752037

20. Orav A, Koel M, Kailas T, Müürisepp M. Comparative analysis of the composition of essential oils and supercritical carbon dioxide extracts from the berries and needles of Estonian juniper (Juniperus communis L.). Procedia Chem 2010; 2:161-167. doi: http://dx.doi.org /10.1016/j.proche. 2009.12.023

21. Dahmane D, Dob T, Chelghoum Ch. Chemical composition of essential oils of Juniperus communis L. obtained by hydrodistillation and microwave-assisted hydrodistllation. J Mater Environ Sci 2015; 6(5):1253-1259.

22. Stoilova IS, Wanner J, Jirovetz L, Trifonova D, Krastev L, Stoyanova A et al., Chemical composition and antioxidant properties of juniper berry
(Juniperus communis L.) essential oil. Bulg J Agric Sci 2014; 20(2): 227-237.

23. Gonny M, Cavaleiro C, Salgueiro L, Casanova J. Analysis of Juniperus communis subsp. alpina needle, berry, wood and root oils by combination of GC, GC/MS and 13C-NMR. Flavour Frag J 2006; 21:99-106. doi: http://dx.doi.org /10.1002/ffj.1527

24. Butkienë R, Nivinskienë O, Mockutë D. Differences in the essential oils of the leaves (needles), unripe and ripe berries of Juniperus communis L. growing wild in Vilnius district (Lithuania). J Essent Oil Res 2006; 18:489-494. doi: http://dx.doi. org/10.1080/10412905.2006.9699150

25. Chatzopoulou P, Katsiotis ST. Study of the essential oil from Juniperus communis "Berries" (Cones) growing wild in Greece. Planta Med 1993; 59:554-556. doi: http://dx.doi.org /10.1055/ s-2006-959760

26. Koukos PK, Papadopoulou KI. Essential oil of Juniperus communis L. grown in Northern Greece: variation of fruit yield and composition. J Essent Oil Res 1997; 9:35-39. doi: http://dx.doi.org/10.1 080/10412905.1997.9700711

27. Shamir F, Ahmadi L, Mirza M, Korori SAA. Secretory elements of needles and berries of Juniperus communis L. ssp. communis and its volatile constituents. Flavour Frag J 2003; 18:425-428. doi: http://dx.doi.org /10.1002/ff.1243

28. Ochocka JR, Asztemborska M, Zook DR, Sybilska D, Perez G, Ossicinis L. Enantiomers of monoterpenic hydrocarbon in essential oils from Juniperus communis. Phytochem 1997; 44 (5):869-873. doi: http://dx.doi.org /10.1016/ S0031-9422(96)00587-0

29. Filipowicz N, Kamiński M, Kurlenda J, Asztemborska M, Ochocka JR. Antibacterial and antifungal activity of juniper berry oil and its selected compounds. Phytotheraphy Res 2003; 17:227231. doi: http://dx.doi.org /10.1002/ptr.1110

30. Pepeljnjak S, Kosalec I, Kalodera Z, Blazević Z. Antimicrobial activity of juniper berry essential oil (Juniperus communis L. Cupressaceae). Acta Pharm 2005; 55:417-422.

31. Haziri A, Faiuku F, Mehmeti A, Govori S, Abazi $S$, Daci $M$ et al. Antimicrobial properties of the 
essential oil of Juniperus communis L. growing wild in east park of Kosovo. Am J Pharma Toxicol 2013; 8(3):128-133. doi: http://dx.doi.org /10.3844/ajptsp.2013.128.133

32. Glisić SB, Milojević SZ, Dimitrijević SI, Orlović AM, Skala DU. Antimicrobial activity of the essential oil and different fractions of Juniperus communis $\mathrm{L}$. and a comparision with some commercial antibiotics. J Serb Chem Soc 2007; 72(4):311-320. doi: http://dx.doi.org/10.2298/JSC0704311G

33. Emami SA, Javadi B, Hassanzadeh MK. Antioxidant activity of the essential oils of different parts of Juniperus communis subsp. hemisphaerica and Juniperus oblonga. Pharmac Biol 2007; 45(10):769-776. doi: http://dx.doi.org/10.1080/ 13880200701585931

34. Misharina TA, Terenina MB, Krikunowa NI. Antioxidant properties of essential oils. Appl Biochem and Microbiol 2009; 45:642-647. doi: http://dx.doi.org /10.1134/S000368380906012X

35. Wei A, Shibamoto T. Antioxidant activities and volatile constituents of various essential oils. J Agric Food Chem 2007; 55:1737-1742. doi: http:// dx.doi.org /10.1021/jf062959x

\title{
Charakterystyka olejku eterycznego uzyskiwanego z szyszkojagód jałowca pospolitego Juniperus communis $\mathrm{L}$. (Cupressaceae)
}

\author{
EWA MAJEWSKA*, MARIOLA KOZŁOWSKA, DOROTA KOWALSKA, ELIZA GRUCZYŃSKA
}

Szkoła Główna Gospodarstwa Wiejskiego w Warszawie

Wydział Nauk o Żywności

ul. Nowoursynowska 159c

02-776 Warszawa

*autor, do którego należy kierować korespondencję: tel.: +48 2259376 12, faks: +48 225937635 ,

e-mail: ewa_majewska@sggw.pl

\section{Streszczenie}

Jałowiec pospolity Juniperus communis L. (Cupressaceae) jest rośliną powszechnie występującą na całej półkuli północnej. Szyszkojagoda jałowca jest surowcem roślinnym dostarczającym cennego olejku eterycznego wykorzystywanego głównie w lecznictwie jako środek o właściwościach bakteriobójczych, moczopędnych, przeciwzapalnych, przeciwreumatycznych oraz przeciwgrzybiczych. $\mathrm{W}$ pracy przedstawiono charakterystykę olejku eterycznego uzyskiwanego z szyszkojagód jałowca pospolitego, metody jego ekstrakcji, skład chemiczny oraz właściwości przeciwbakteryjne i przeciwgrzybicze, jak również przeciwutleniające.

Słowa kluczowe: Juniperus communis L., olejki eteryczne, szyszkojagoda jałowca pospolitego 